\section{Nauplius}

The Journal of The

Brazilian Crustacean Society

e-ISSN 2358-2936

www.scielo.br/nau www.crustacea.org.br
This article is part of the special series

offered by the Brazilian Crustacean Society

in honor to Ludwig Buckup

his dedication and contributions to the

development of Carcinology

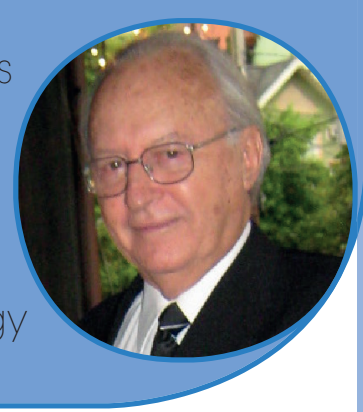

Original Article

\title{
Ludwig Buckup's academic life and his contribution to Carcinology
}

\author{
Alessandra Angélica de Pádua Bueno' (iD) orcid.org/0000-0001-7809-7189 \\ Paula Beatriz Araujo 2 iD orcid.org/0000-0002-7587-3936 \\ Sandro Santos ${ }^{3}$ iD orcid.org/0000-0001-9305-1154
} 1 Laboratório de Carcinologia, Departamento de Biologia, Universidade Federal de
Lavras, Lavras, Minas Gerais, Brazil.

AAPB E-mail: aapbueno@yahoo.com.br

2 Laboratório de Carcinologia, Programa de Pós-Graduação em Biologia Animal, Departamento de Zoologia, Instituto de Biociências, Universidade Federal do Rio Grande do Sul, Porto Alegre, Rio Grande do Sul, Brazil.

PBA E-mail: pabearaujo@gmail.com

3 Laboratório de Carcinologia, Programa de Pós-Graduação em Biodiversidade Animal Animal, Departamento de Ecologia e Evolução, Centro de Ciências Naturais e Exatas, Universidade Federal de Santa Maria, Santa Maria, Rio Grande do Sul, Brazil. ss E-mail: sandro.santos@ufsm.br

ZOOBANK http://zoobank.org/urn:1sid:zoobank.org:pub:27A54805-B52D-4AC2BA7C-E33A8289D16A

\section{ABSTRACT}

Ludwig Buckup holds a Bachelor's degree in Natural History in 1954 from the Federal University of Rio Grande do Sul (UFRGS), Porto Alegre, and a Ph.D. in Zoology from the University of Tübingen, Germany, in 1958. He joined UFRGS as a Professor in 1958, from where he retired in 1990. During this period he was fully devoted to his career of professor and scientist. His investigations in the area of Carcinology covered mainly the Parastacidae

CORRESPONDING AUTHOR Alessandra A. de Pádua Bueno aapbueno@yahoo.com.br

SUBMITTED 5 February 2018 ACCEPTED 2 March 2018 PUBLISHED 26 March 2018

Guest Editors

Alessandra A. de Pádua Bueno and Sandro Santos

DOI 10.1590/2358-2936e2018007

\section{(cc) BY}

All content of the journal, except where identified, is licensed under a Creative Commons attribution-type BY

Nauplius, 26: e2018007 and Aeglidae families. Even after he retired, Professor Buckup participated in numerous research and extension activities inside and outside the University. Always engaged in environmental causes, he actively takes part in debates and lectures about the environment and conservation in the city of Porto Alegre and other cities in the state of Rio Grande do Sul. His career is highlighted by important steps for the construction of academic spaces and the development and consolidation of Carcinology, in particular for the Brazilian Crustacean Society.

\section{KEY WORDS}

Biography, Crustacea, crayfish, Aeglidae, Parastacidae. 
Ludwig Buckup, a descendant of German immigrants, was born on March 25, 1932, in the city of São Paulo. His education initiated in São Paulo and later in Rio de Janeiro. Enthusiastic since childhood for matters related to nature, he obtained a bachelor's degree in Natural History in 1954, and a licentiate degree in 1955 (Fig. 1A) at the University of Rio Grande do Sul, now known as the Federal University of Rio Grande do Sul (UFRGS), in Porto Alegre. Looking forward to a good professional career, he applied for a one-year scholarship from DAAD - Deutscher Akademischer Austauschdienst (German Academic Exchange Service), to carry out a research internship at the Zoophysiologisches Institut of the University of Tübingen, Tübingen, Germany. Professor Dr. Herman Risler received him and soon he was invited to do a Ph.D. (Promotion) on a theme of Entomology. In fact, ten months after his arrival in Tübingen, his doctoral thesis was completed and approved on October 25, 1958 , with the distinction "cum laude" (with praise).

Returning to Brazil in December 1958, he joined the Federal University of Rio Grande do Sul as a professor, where he was given the task of teaching the newly created discipline of Biogeography, which he fulfilled during 32 years until his formal retirement in 1990. In 1983, he became a Full Professor, with full-time dedication to the Department of Zoology of the Institute of Biosciences at UFRGS, where he developed his research until his definitive departure from the laboratory in 2010. His link with UFRGS lasted 55 years, with outstanding performance in teaching, research and university extension programs, contributing with his point of view, energy and competence to the formative role, integration, and the cultural and social function of the university.

Ludwig Buckup always showed an eclectic profile, encouraging the cultural and artistic areas, both inside and outside of UFRGS. He assumed several tasks in the university administration and in the cultural and scientific environment of the city of Porto Alegre. He was president of the Porto Alegre's Symphonic Orchestra Foundation from 1995 to 1998 . He also excelled in activities that prioritized the defense of the environment and the preservation of natural resources, especially in Rio Grande do Sul.

He participated in administrative activities at the University in the position of Dean of the University
Extension Programs at UFRGS, from 1980 to 1984. During this period, under his coordination, the Unicultura Program was created, with its "Unimúsica", "Unidança”, "Unicena”, "Doze-e-Trinta e Seis-e-Meia” and "Uniartes" projects. As Dean and enthusiastic he stimulated the new generations to develop an interest in classical music and to play classical instruments. He also created and administered the Prelúdio Project, which, alongside with "Unimúsica”, remain nowadays in the cultural agenda of UFRGS.

He was an active professor, establishing the disciplines of Biogeography and Biological Oceanography in the Course of Natural History offered by UFRGS, from the 1960's on. In 1971, he encouraged and participated in the creation of the Department of Zoology of UFRGS. In 1975, he acted decisively for the startup of Ecology Specialization Course and, in 1977, for the creation of the Post-Graduate Program in Ecology, and was the first Coordinator of the course. In 1994, he contributed effectively to the creation of the Post-Graduate Program in Animal Biology, where he was a teacher and supervisor until his retirement.

As a researcher, in addition to UFRGS, he worked at the Museu Riograndense de História Natural (Rio Grandense Museum of Natural Sciences), an organ linked to the current Zoobotanic Foundation of Rio Grande do Sul, where he held the position of Director (1962 to 1966) and member of the Advisory Board (1992 to 1996, 2003 to 2007). Together with Professor Padre Balduino Rambo, he was the co-founder of the Rio-Grandense Museum of Natural Sciences of the Culture Division of the Secretary of State for Education and Culture of Rio Grande do Sul (now the Natural Sciences Museum of the Zoological Society of the Environment Secretariat of RGS). At the Museum of Natural Sciences, in 1957, he was one of the founders of the Iheringia, a scientific journal, which started with the Zoology Series.

He participated actively in the creation and as a counselor of scientific entities boards. It is worth mentioning the foundation of the Brazilian Crustacean Society, of which he was president from 1983 to 1986 and member of the Council from 2009 to 2012. In the years 1980 to 1990 he was an active member of the Sociedade Brasileira para o Progresso da Ciência (Brazilian Society for the Progress of Science) - Rio Grande do Sul (SBPC), occupying the position of 


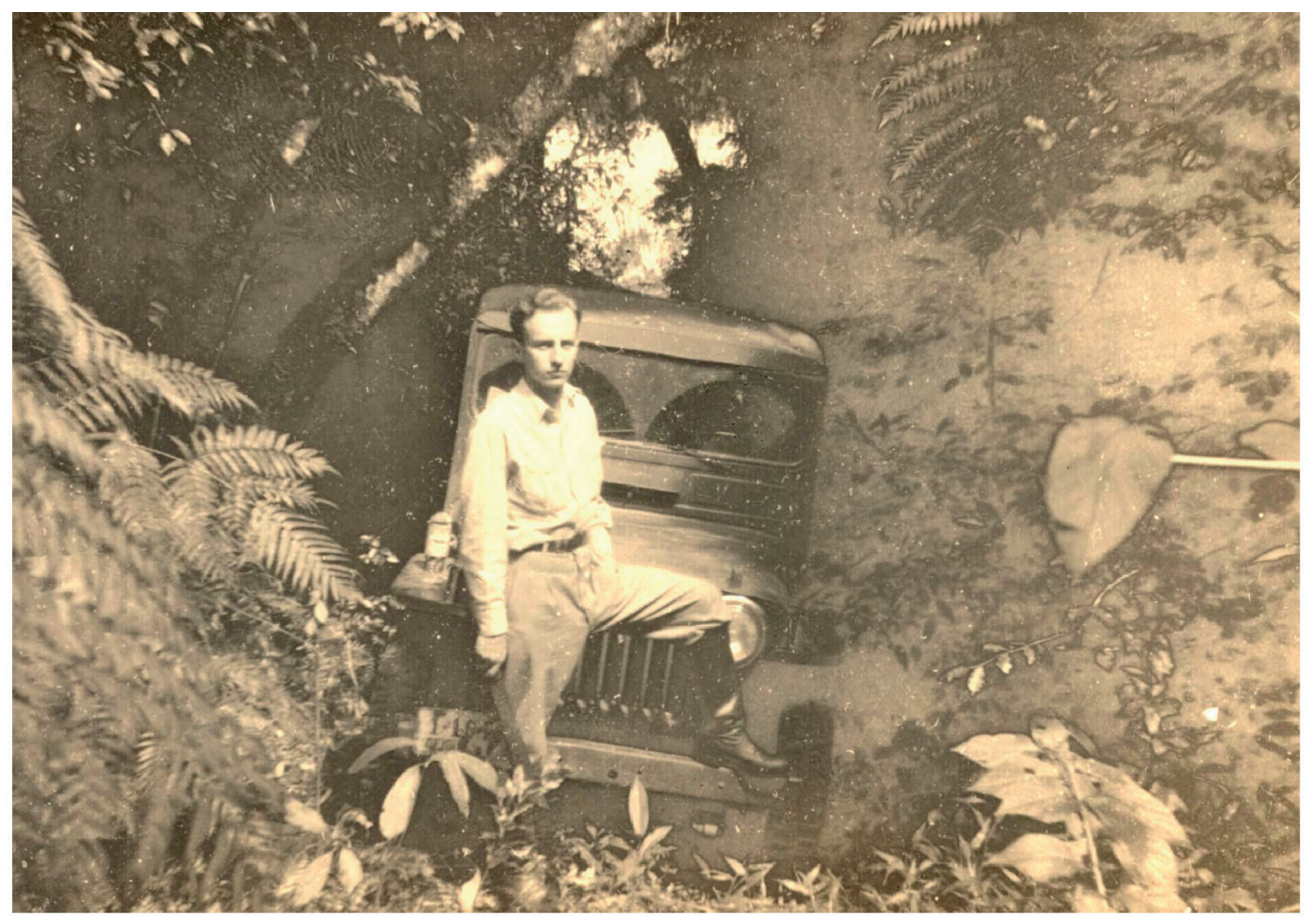

A

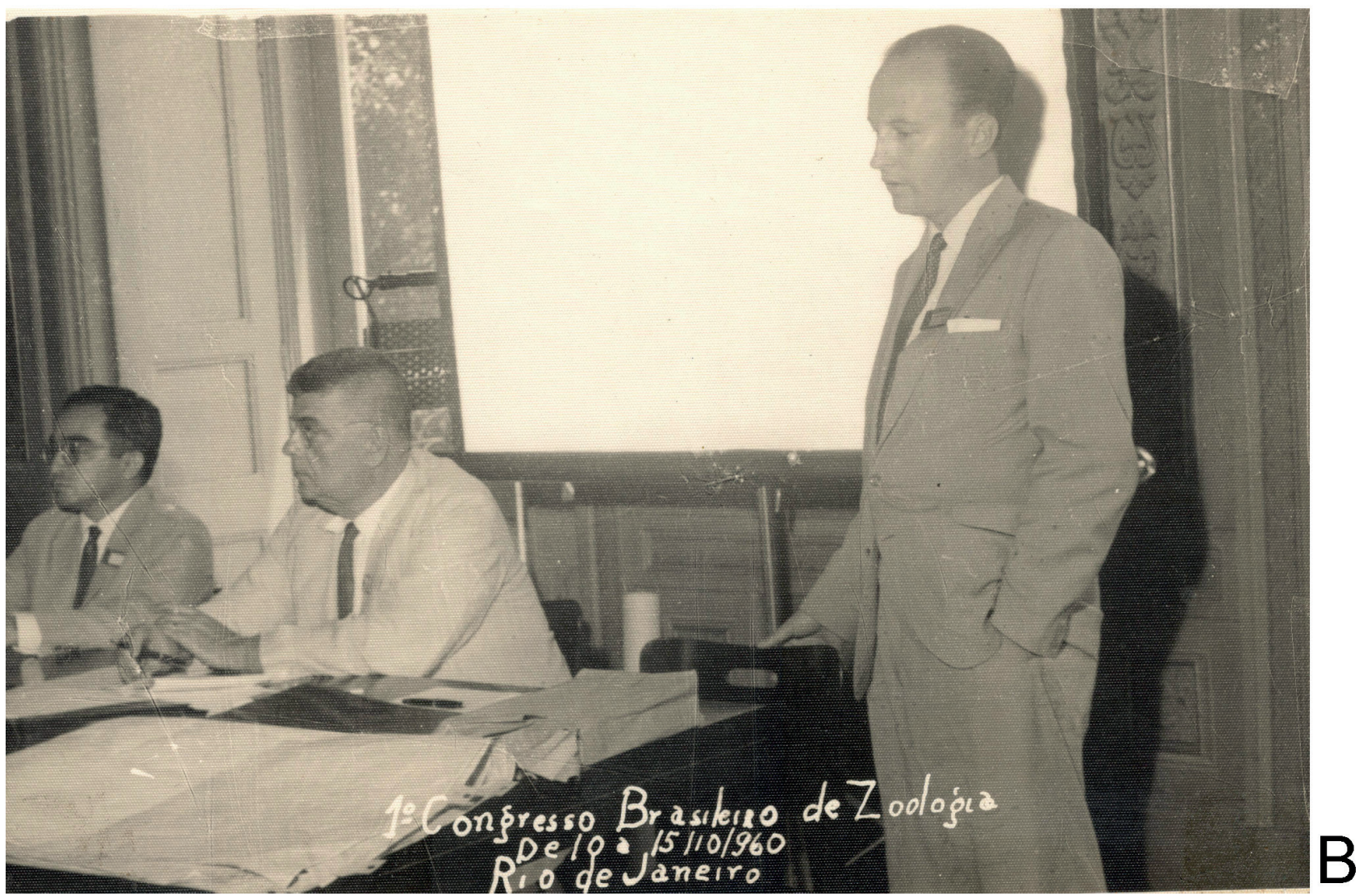

Figure 1. Ludwig Buckup in the beginning of his career. A, As a student, in a field trip (1952); B, During the I Brazilian Congress of Zoology, Rio de Janeiro, 1960. Photographs of L. Buckup’s personal collection. 
regional secretary from 1992 to 1994 . He was a full member of the Federal Council of Biology, composing the first Council Board. He had intense participation in the regulation of the Biologist profession at the national level. He served as a full member of the Superior Council of the Foundation for Research Support of the State of Rio Grande do Sul in the 1990s.

He was honored in 2012 with the "Medalha Cidade de Porto Alegre", awarded by the Porto Alegre City Hall for his work and activities in the area of ecology and zoology (Fig. 2A). He was awarded with the Alexandre Rodrigues Ferreira Prize by the Brazilian Society of Zoology and received the Biology Merit Prize 2000 - Trajetória Profissional, from Regional Council of Biology - 3rd Region (Paraná, Santa Catarina and Rio Grande do Sul). In the same year, he was honored with a tribute by the Brazilian Crustacean Society. In 2014, he received from UFRGS the title of Professor Emeritus in recognition of his vision of the university, innovative spirit and relevant services to the University (Fig. 2B).

In his academic activities, he interacted with a hundred collaborators, which is reflected in the co-authorship of his scientific production. His intellectual contribution, involving several themes, first in Entomology (Buckup, 1957a; 1959) and later in Carcinology (several publications), comprises complete original scientific articles published in peer-reviewed journals, including the description of new species (Tab. 1). He also participated in the publication and organization of books, books chapters, and took part in scientific events, gave lectures, carried out technical works (advice, consultancy, opinions and technical reports) and guided undergraduate (undergraduate scientific advice and scholarships) and graduate courses (monographs, master's and doctorate theses). Professor Buckup also organized and coordinated national and international scientific events (Fig. 1B). He has been a consultant for more than 20 scientific journals, and several science and education funding agencies in Brazil and abroad. Many of his former students excelled in their areas of specialization, occupying positions in several Higher Education Institutions in Brazil. Professor Buckup and his former students currently represent an important source of knowledge about the taxonomic, biological and ecological diversity of Neotropical freshwater carcinofauna. Particularly, his pioneering investigation on the composition of the

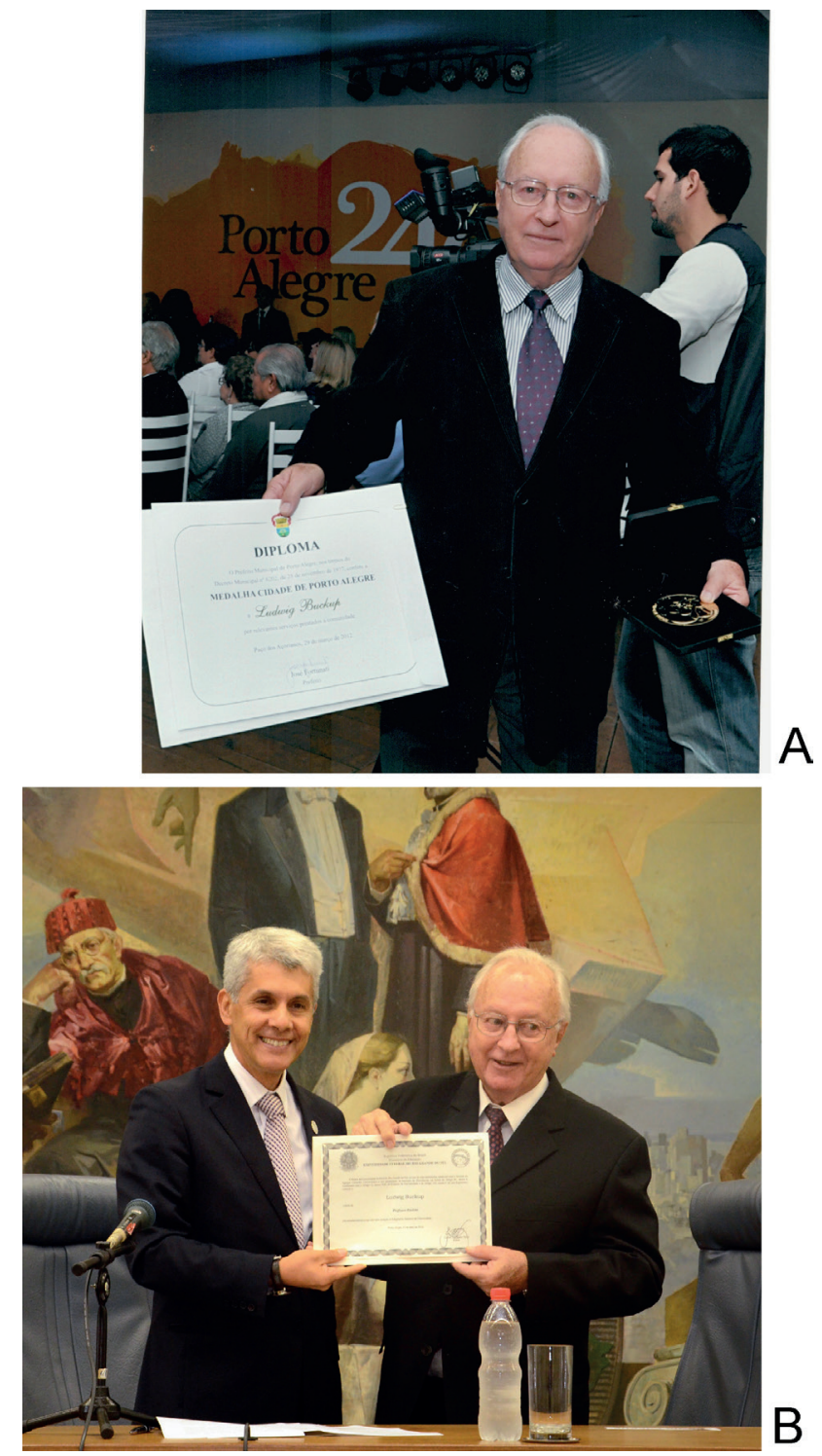

Figure 2. Special recognitions received by Ludwig Buckup. A, Ludwig Buckup receiving the "Medalha Cidade de Porto Alegre" (2012); photograph of L. Buckup's personal collection. B, Ludwig Buckup receiving from Dr. Carlos Alexandre Netto, Rector of UFRGS, Honor to Merit at the Federal University of Rio Grande do Sul (2016); photograph: Gustavo Diehl/UFRGS.

southern Brazilian limnic fauna should be emphasized (Buckup and Thomé, 1962; Buckup and Bento, 1999; Buckup and Bond-Buckup, 1999; Buckup et al., 2007a; Melo et al., 2008). Several articles published by his research group constitute an essential basis for the continuation of research on Neotropical biota. The family Parastacidae was extensively investigated by his research group (Fontoura and Buckup, 1989a; 1989b; 1991; Buckup and Rossi, 1993; Buckup and Bond-Buckup, 1994; Almeida and Buckup, 1997; 1999; 2000; Buckup, 1999b; 2003; Crandall et al., 
Table 1. New species described by Ludwig Buckup.

\begin{tabular}{|c|c|c|c|}
\hline Class & Order & Family & Species \\
\hline \multirow{3}{*}{ Insecta } & & \multirow{2}{*}{ Pentatomidae } & Agroecus tenebricosus Buckup, 1957 \\
\hline & & & Agroecus brevicornis Buckup, 1957 \\
\hline & & Reduviidae & Apiomerus riograndensis Buckup, 1957 \\
\hline \multirow{36}{*}{ Crustacea } & \multirow{4}{*}{ Isopoda } & Dubioniscidae & Novamundoniscus meridionalis (Araujo \& Buckup, 1994) \\
\hline & & Philosciidae & Benthana taeniata Araujo \& Buckup, 1994 \\
\hline & & \multirow{2}{*}{ Platyarthridae } & Trichorhina acuta Araujo \& Buckup, 1994 \\
\hline & & & Trichorhina bicolor Araujo \& Buckup, 1996 \\
\hline & \multirow{32}{*}{ Decapoda } & \multirow{30}{*}{ Aeglidae } & Aegla camargoi Buckup \& Rossi, 1977 \\
\hline & & & Aegla franciscana Buckup \& Rossi, 1977 \\
\hline & & & Aegla leptodactyla Buckup \& Rossi, 1977 \\
\hline & & & Aegla plana Buckup \& Rossi, 1977 \\
\hline & & & Aegla serrana Buckup \& Rossi, 1977 \\
\hline & & & Aegla grisella Bond-Buckup \& Buckup, 1994 \\
\hline & & & Aegla inconspicua Bond-Buckup \& Buckup, 1994 \\
\hline & & & Aegla inermis Bond-Buckup \& Buckup, 1994 \\
\hline & & & Aegla intercalata Bond-Buckup \& Buckup, 1994 \\
\hline & & & Aegla itacolomiensis Bond-Buckup \& Buckup, 1994 \\
\hline & & & Aegla jarai Bond-Buckup \& Buckup, 1994 \\
\hline & & & Aegla lata Bond-Buckup \& Buckup, 1994 \\
\hline & & & Aegla leptochela Bond-Buckup \& Buckup, 1994 \\
\hline & & & Aegla ligulata Bond-Buckup \& Buckup, 1994 \\
\hline & & & Aegla longirostri Bond-Buckup \& Buckup, 1994 \\
\hline & & & Aegla marginata Bond-Buckup \& Buckup, 1994 \\
\hline & & & Aegla microphthalma Bond-Buckup \& Buckup, 1994 \\
\hline & & & Aegla obstipa Bond-Buckup \& Buckup, 1994 \\
\hline & & & Aegla parva Bond-Buckup \& Buckup, 1994 \\
\hline & & & Aegla ringueleti Bond-Buckup \& Buckup, 1994 \\
\hline & & & Aegla rossiana Bond-Buckup \& Buckup, 1994 \\
\hline & & & Aegla septentrionalis Bond-Buckup \& Buckup, 1994 \\
\hline & & & Aegla spinipalma Bond-Buckup \& Buckup, 1994 \\
\hline & & & Aegla spinosa Bond-Buckup \& Buckup, 1994 \\
\hline & & & Aegla violacea Bond-Buckup \& Buckup, 1994 \\
\hline & & & Aegla pomerana Bond-Buckup \& Buckup, 2010 \\
\hline & & & Aegla muelleri Bond-Buckup \& Buckup, 2010 \\
\hline & & & Aegla renana Bond-Buckup \& Buckup, 2010 \\
\hline & & & Aegla leachi Bond-Buckup \& Buckup, 2012 \\
\hline & & & Aegla lancinhas Bond-Buckup \& Buckup, 2015 \\
\hline & & \multirow{2}{*}{ Parastacidae } & Parastacus laevigatus Buckup \& Rossi, 1980 \\
\hline & & & Parastacus fluviatilis Ribeiro \& Buckup, 2016 \\
\hline
\end{tabular}

2000; Horn et al., 2004; 2008; Vinagre et al., 2004; Reid et al., 2006; Buckup et al., 2007b; 2007c; Noro et al., 2007; 2008; Noro and Buckup, 2010; SilvaCastiglioni et al., 2010). From 1979 on, he published several articles about the family Aeglidae (Buckup and Rossi, 1977; Bond-Buckup and Buckup, 1994; 1999a; 2000; Buckup and Bond-Buckup, 1998; Bueno et al., 2000; Noro and Buckup, 2002; 2003; Boos et al., 2006; Sokolowicz et al., 2006; Bond-Buckup et al., 2008; 2010a; 2010b; Gonçalves et al., 2009; Santos et al., $2009 ; 2010)$. In relation to the aquatic biota, one can highlight the publications with caridean prawns such as Setz and Buckup (1977) and Bond-Buckup and Buckup (1982; 1983; 1988; 1989; 1999b). Terrestrial crustaceans, particularly the Isopoda, were also the focus of several studies (Araujo and Buckup, 1994a; 1994b; 1996a; 1996b; Araujo et al., 1996). Professor Buckup also had active participation in discussions about the conservation of species of the Brazilian fauna (Amaral et al., 2008; Magris et al., 2010). Species were described in his honor, reflecting his intense effort to generate knowledge about the South American fauna (Tab. 2).

After his departure from the University, Professor Buckup continued to collaborate with several scientists and to publish scientific articles, although at a less intense pace (Fig. 3). Currently, he dedicates most of his time to other activities such as gastronomy, bromeliads, 
Table 2. Species described in honor of Ludwig Buckup.

\begin{tabular}{lll}
\hline \multicolumn{1}{c}{ Higher taxa } & \multicolumn{1}{c}{ Species } \\
\hline Mollusca & Olividae & Olivancillaria buckuporum Thomé, 1966 \\
\hline \multirow{3}{*}{ Crustacea } & Decapoda, Alpheidae & Alpheus buckupi Almeida, Terossi, Araújo-Silva \& Mantelatto, 2013 \\
\cline { 2 - 3 } & Decapoda, Aeglidae & Aegla ludwigi Santos \& Jara, 2013 \\
\cline { 2 - 3 } & Isopoda, Oniscidea, Scleropactidae & Circoniscus buckupi Campos-Filho \& Araujo, 2011 \\
\hline
\end{tabular}

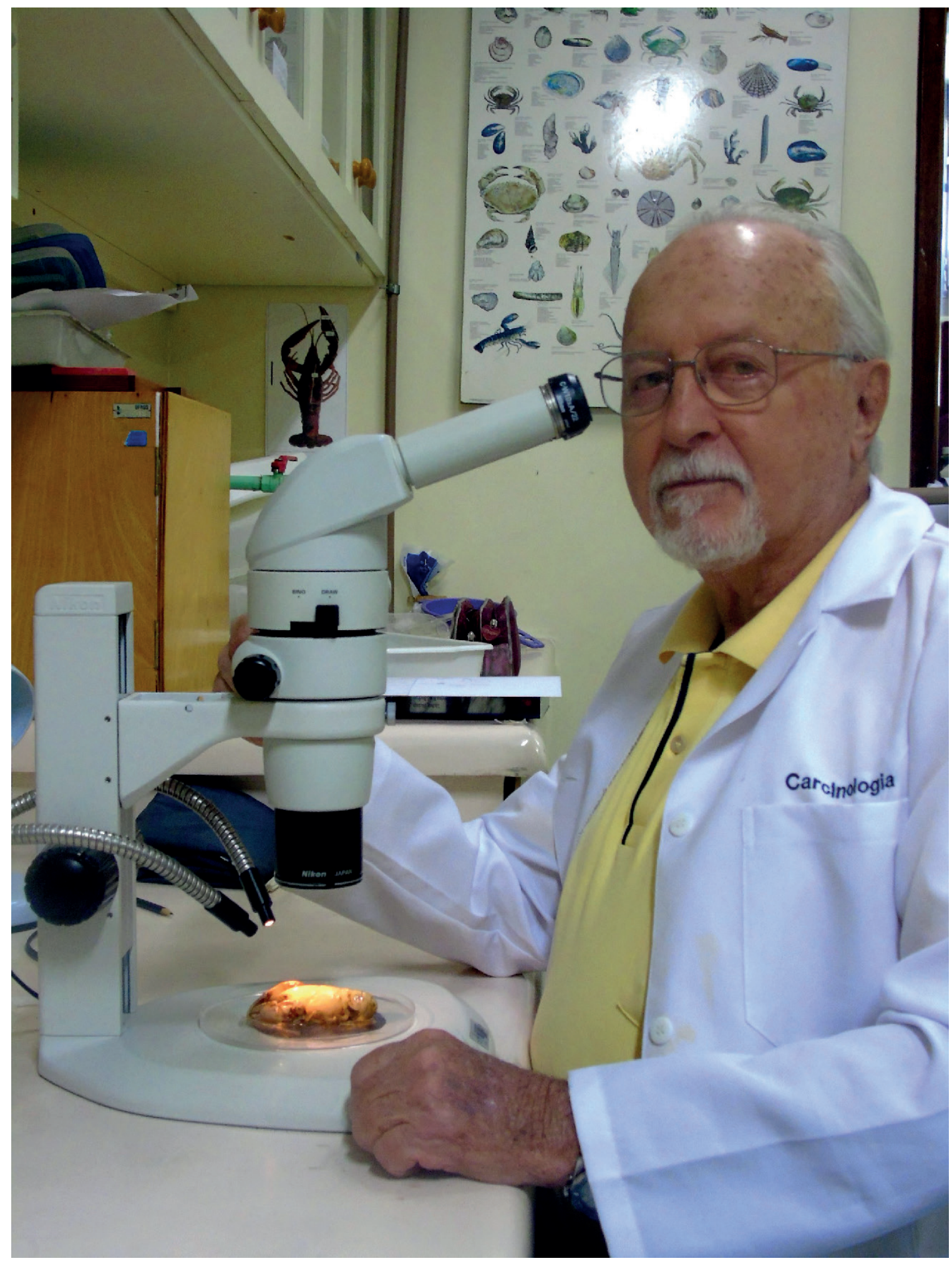

Figure 3. Ludwig Buckup in the present time (2017) at the Carcinology Laboratory of UFRGS. Photograph: Georgina Bond- Buckup. 
fishing and travel, sharing his joy and good humor with his friends. This special series is dedicated to Professor Ludwig Buckup for opening many avenues for young scientists who, with his example and encouragement, continued his pioneering work, advancing the field of Carcinology. We are very grateful to him who made these opportunities possible and with whom we are still learning and sharing good moments until today.

\section{ACKNOWLEDGEMENTS}

Our thanks to Georgina Bond-Buckup for her kindness in providing us with information about the life, career and photographs of Dr. Ludwig Buckup. To CNPq for the Research Productivity fellowship to PBA and SS.

\section{References}

Almeida, A.O. and Buckup, L. 1997. Aspectos anatômicos e funcionais do aparelho reprodutor de Parastacus brasiliensis (Von Martens) (Crustacea, Decapoda, Parastacidae). Revista brasileira de Zoologia, 14: 497-509.

Almeida, A.O. and Buckup, L. 1999. Caracteres sexuais primários e secundários do lagostim Parastacus defossus Faxon 1898 (Crustacea, Parastacidae). Nauplius, 7: 113-126.

Almeida, A.O. and Buckup, L. 2000. Occurence of protandric hermaphroditism in a population of the neotropical freshwater crayfish Parastacus brasiliensis (Parastacidae). Journal of Crustacean Biology, 20: 224-230.

Almeida, A.O.; Terossi, M.; Araújo-Silva, C.L. and Mantelatto, F.L. 2013. Description of Alpheus buckupi spec. nov., a new amphiAtlantic snapping shrimp (Caridea: Alpheidae), based on morphological and molecular data. Zootaxa, 3652: 437-452.

Amaral, A.C.Z.; Ribeiro, C.V.; Mansur, M.C.D.; Santos, S.B. dos; Avelar, W.E.P.; Matthews-Cascon,H.; Leite, F.P.P.; Melo, G.A.S. de; Coelho, P.A.; Bond-Buckup, G.; Buckup, L.; Ventura, C.R.R.; Tiago, C.G. 2008. A Situação de Ameaça dos Invertebrados Aquáticos no Brasil. p. 57-293. In: A.B.M. Machado; G.M. Drummond, and A.P. Paglia (eds), Livro Vermelho da Fauna Brasileira Ameaçada de Extinção, Vol. 1. Belo Horizonte, Gráfica e Editora Rona Ltda.

Araujo, P.B. and Buckup, L. 1994a. Nova espécie de Trichorhina Budde-Lund,1908 (Crustacea, Isopoda, Platyarthridae). Iheringia, Série Zoologia, 77: 129-134.

Araujo, P.B. and Buckup, L. 1994b. Two New Species Of Terrestrial Isopoda From Southern Brazil (Crustacea,Oniscoidea). Spixiana, 17: 269-274.

Araujo, P.B. and Buckup, L. 1996a. Novos registros e uma espécie nova de Trichorhina Budde-Lund (Isopoda, Oniscidea, Platyarthridae) do Sul do Brasil. Revista brasileira de Zoologia, 13: 799-810.

Araujo, P.B. and Buckup, L. 1996b. Ocorrência de Nagurus Holthuis, 1949 (Isopoda, Trachelipodidae) no sul do Brasil. Nauplius, 4: 161-163.

Araujo, P.B.; Buckup, L. and Bond-Buckup, G. 1996. Isópodos terrestres (Crustacea, Oniscidea) de Santa Catarina e Rio Grande do Sul, Brasil. Iheringia, Série Zoologia, 81: 111-138.

Bond-Buckup, G. and Buckup, L. 1982. O ciclo reprodutor de Macrobrachium borellii e M. potiuna (Crustacea, Decapoda, Palaemonidae) e suas relações com a temperatura. Revista Brasileira de Biologia, 42: 473-483.

Bond-Buckup, G. and Buckup, L. 1983. O cultivo de Macrobrachium borellii e de M. potiuna em laboratório (Crustacea, Decapoda, Palaemonidae). Revista Brasileira de Biologia, 430: 177-190.

Bond-Buckup, G. and Buckup, L. 1988. O ciclo da intermuda em Macrobrachium borellii (Nobili,1896) (Crustacea, Decapoda, Palaemonidae). Revista brasileira de Zoologia, 5: 45-59.

Bond-Buckup, G. and Buckup, L. 1989. Os Palaemonidae de águas continentais do Brasil meridional (Crustacea). Revista Brasileira de Biologia, 49: 883-896.

Bond-Buckup, G. and Buckup, L. 1994. A família Aeglidae (Crustacea, Decapoda, Anomura). Arquivos de Zoologia, 32: 159-346.

Bond-Buckup, G. and Buckup, L. 1999a. Aeglidae. p. 362-382. In: G. Bond-Buckup and L. Buckup, (eds), Os Crustáceos do Rio Grande do Sul. Porto Alegre, Editora da Universidade Federal do Rio Grande do Sul.

Bond-Buckup, G. and Buckup, L. 1999b. Caridea. p. 300-318. In: G. Bond-Buckup and L. Buckup (eds), Os crustáceos do Rio Grande do Sul. Porto Alegre, Editora da Universidade Federal do Rio Grande do Sul.

Bond-Buckup, G. and Buckup, L. 2000. Aegla rosanae Campos Jr., um novo sinônimo de Aegla paulensis Schmitt (Crustacea, Aeglidae). Revista brasileira de Zoologia, 17: 385-386.

Bond-Buckup, G; Jara, C.G.; Buckup, L; Bueno, A.A.P.; PerezLosada, M. and Crandall, K.A. 2010a. Description of a new species of Aeglidae, and new records of related species from river basins in Argentina. Zootaxa, 2343:18-30.

Bond-Buckup, G; Jara, C.G.; Buckup, L; Perez-Losada, M.; Bueno, A.A.P.; Crandall, K.A. and Santos, S. 2010b. New species and new records of endemic freshwater crabs from the Atlantic forest in southern Brazil (Anomura: Aeglidae). Journal of Crustacean Biology, 30: 495-502.

Bond-Buckup, G; Jara, C.G.; Perez-Losada, M.; Buckup, L. and Crandall, K.A. 2008. Global diversity of crabs (Aeglidae: Anomura: Decapoda) in freshwater. Hydrobiologia, 595: 267-273.

Boos, H.; Castiglioni, D.S.; Schacht, K.; Buckup, L. and BondBuckup, G. 2006. Crescimento de Aegla jarai Bond-Buckup \& Buckup (Crustacea, Anomura, Aeglidae). Revista brasileira de Zoologia, 23: 490-496.

Buckup, L. 1957a. Contribuição ao conhecimento do gênero Apiomerus no Brasil meridional (Hemiptera, Reduviidae, Apiomerinae). Revista Brasileira de Biologia, 17: 51-57.

Buckup, L. 1957b. Catálogo dos moluscos do Museu Riograndense de Ciências Naturais. Iheringia, Série Zoologia, 1: 1-39.

Buckup, L. 1959. Der Kopf von Myrsidea cornicis (De Geer) (Mallophaga, Amblycera). Zoologische Jahrbuecher, Abteilung Fuer Anatomie Und Ontogenie Der Tiere, 77: 241-288.

Buckup, L. 1998. Malacostraca - Eucarida. Astacidea. p. 373-375. In: P.S. Young (ed), Catalogue of Crustacea of Brazil. Rio de Janeiro, Editora da Universidade Federal do Rio de Janeiro.

Buckup, L. 1999a. A Fauna e as paisagens do Rio Grande do Sul na visão dos viajantes alemães dos séculos passados. p. 
47-62. In: V. Rohden (ed), Retratos de cooperação científica e cultural: 40 anos do Instituto Cultural Brasileiro Alemão. Porto Alegre, Editora da PUCRS.

Buckup, L. 1999b. Parastacidae. p. 319-327. In: L. Buckup and G. Bond-Buckup (eds), Os Crustáceos do Rio Grande do Sul. Porto Alegre, Editora da Universidade Federal do Rio Grande do Sul.

Buckup, L. 2003. Família Parastacidae. p. 117-141. In: G.A.S. Melo (org), Manual de identificação dos Crustacea Decapoda de água doce do Brasil. São Paulo, Loyola.

Buckup, L. and Bento, F.M. 1999. Ordem Amphipoda - Subordem Gammaridea. p. 177-188. In: L. Buckup, and G. Bond-Buckup (eds), Os Crustáceos do Rio Grande do Sul. Porto Alegre, Editora da Universidade Federal do Rio Grande do Sul.

Buckup, L. and Bond-Buckup, G. 1994. Parastacidae e Aeglidae (Crustacea, Decapoda) Neotropicais do Museu de Berlim, Alemanha. Nauplius, 2: 17-27.

Buckup, L. and Bond-Buckup, G. 1998. Malacostraca - Eucarida - Aeglidae. p. 431-437. In: P.S. Young (ed), Catalogue of Crustacea of Brazil. Rio de Janeiro, Museu Nacional.

Buckup, L. and Bond-Buckup, G. 1999. Os Crustáceos do Rio Grande do Sul. Porto Alegre, Editora da Universidade Federal do Rio Grande do Sul, 503p.

Buckup, L.; Bueno, A.A.P.; Bond-Buckup, G.; Casagrande, M. and Majolo, F. 2007a. The benthic macroinvertebrate fauna of highland streams in southern Brazil: composition, diversity and structure. Revista brasileira de Zoologia, 24: 294-301.

Buckup, L.; Dutra, B.K.; Ribacki, F.P.; Fernandes, F.A.; Noro, C.K.; Oliveira, G.T. and Vinagre, A.P. 2007b. Seasonal Variations in the biochemical composition of the crayfish Parastacus defossus (Crustacea, Decapoda) in its natural environment. Comparative Biochemistry and Physiology. B, Biochemistry \& Molecular Biology, 1: 1-26.

Buckup, L.; Noro, C.K. and Bond-Buckup, G. 2007c. p. 247252. Os "Lagostins-da-Água-Doce" da bacia do Guaiba um caso de endemismo no sul do Brasil. In: T. Guerra (ed), Conhecer para gerenciar - Aspectos Ambientais e Sociais da Bacia Hidrográfica do Lago Guálba. Porto Alegre, Comitê da Bacia Hidrográfica do Lago Guaíba.

Buckup, L. and Rossi, A. 1977. O gênero Aegla no Rio Grande do Sul, Brasil (Crustacea, Decapoda, Aeglidae). Revista Brasileira de Biologia, 37: 879-892.

Buckup, L. and Rossi, A. 1980. O gênero Parastacus no Brasil (Crustacea, Decapoda, Parastacidae). Revista Brasileira de Biologia, 40: 663-681.

Buckup, L. and Rossi, A. 1993. Os Parastacidae do Espaco Meridional Andino (Crustacea, Astacidea). Revista Brasileira de Biologia, 53: 167-176.

Buckup, L. and Thomé, J.W. 1962. I Campanha oceanográfica do Museu Riograndense de Ciências Naturais - A Viagem do Pescal II em julho de 1959. Iheringia, Série Zoologia, 20: 1-42.

Bueno, A.A.P.; Bond-Buckup, G. and Buckup, L. 2000. Crescimento de Aegla platensis Schmitt em ambiente natural (Crustacea, Decapoda, Aeglidae). Revista brasileira de Zoologia, 17: 51-60.

Campos-Filho, I.S. and Araujo, P.B. 2011. Two new troglobitic species of Scleropactidae (Crustacea: Isopoda: Oniscidea) from Pará, Brazil. Nauplius, 19: 27-39.

Crandall, K.A.; Fetzner, J.W.; Jara, C.G. and Buckup, L. 2000. On the phylogenetic positioning of the South American freshwater crayfish genera (Decapoda: Parastacidae). Journal of Crustacean Biology, 20: 530-540.

Fontoura, N.F. and Buckup, L. 1989a. Dinâmica populacional e reprodução em Parastacus brasiliensis (Von Martens, 1869) (Crustacea, Decapoda, Parastacidae). Revista Brasileira de Biologia, 49: 911-921.

Fontoura, N.F. and Buckup, L. 1989b. O Crescimento de Parastacus brasiliensis (Von Martens, 1869) (Crustacea, Decapoda, Parastacidae). Revista Brasileira de Biologia, 49: 897-909.

Fontoura, N.F. and Buckup, L. 1991. Biomassa e produtividade de uma população natural de Parastacus brasiliensis (Von Martens, 1869) (Crustacea, Decapoda, Parastacidae). Revista Brasileira de Biologia, 51: 289-293.

Gonçalves, R.; Bond-Buckup, G. and Buckup, L. 2009. Crescimento de Aegla itacolomiensis (Crustacea, Decapoda) em um arroio da Mata Atlântica no sul do Brasil. Iheringia, Série Zoologia, 99: 1-6.

Horn, A.C.M. and Buckup, L. 2004. Morfologia setal de Parastacus brasiliensis (von Martens) (Crustacea, Decapoda, Parastacidae). Revista brasileira de Zoologia, 21: 765-768.

Horn, A.C.M.; Buckup, L.; Noro, C.K. and Barcelos, D. 2008. Morfologia externa de Parastacus brasiliensis (Decapoda, Parastacidae). Iheringia, Série Zoologia, 98: 148-155.

Magris, R.A.; Bond-Buckup, G.; Magalhães, C.; Mantelatto, F.L.; Reid, J.W.; Loureiro, L.M.A.E.; Coelho, P.A.; Santana, W.; Buckup, L.; Rocha, S.S.; Bueno, S.L.S.; Pinheiro, M.A.A.; D’Incao, F.; Ivo, C.T.C.; Dias Neto, J.; Rodrigues, E.S.; Araujo, P.B.; Boos Junior., H. and Duarte, L.F.A. 2010. Quantification of extinction risk for crustacean species: an overview. Nauplius, 18:129-135.

Melo, A.S.; Buckup, L.; Bond-Buckup, G.; Castiglioni, D.S. and Bueno, A.A.P. 2008. Invertebrados Aquáticos. p. 58-75. In: G. Bond-Buckup (ed), Biodiversidade dos Campos de Cima da Serra. 1ed. Porto Alegre, Libretos Porto Alegre, Vol. 1.

Noro, C.K. and Buckup, L. 2002. Biologia reprodutiva e ecologia de Aegla leptodactyla Buckup \& Rossi (Crustacea, Anomura, Aeglidae). Revista brasileira de Zoologia, 19: 1063-1074.

Noro, C.K. and Buckup, L. 2003. O crescimento de Aegla leptodactyla Buckup \& Rossi (Crustacea, Anomura, Aeglidae). Revista brasileira de Zoologia, 20: 191-198.

Noro, C.K. and Buckup, L. 2008. Estrutura populacional e biologia reprodutiva de Parastacus defossus (Crustacea: Decapoda: Parastacidae). Revista brasileira de Zoologia, 25: 624-629.

Noro, C.K. and Buckup, L. 2010. The burrows of Parastacus defossus (Decapoda: Parastacidae). Revista brasileira de Zoologia, 27: 341-346.

Noro, C.K.; Buckup, L. and Bond-Buckup, G. 2005. The juvenile stages of Parastacus brasiliensis (Von Martens, 1869) (Crustacea, Decapoda, Parastacidae). Journal of Natural History, 39: 1851-1873.

Noro, C.K.; Castiglioni, D.S.; Lopez-Greco, L.; Buckup, L. and Bond-Buckup, G. 2007. Morphology of the vasa deferentia of Parastacus defossus and P. varicosus and comparison within the Parastacidae. Nauplius, 15: 43-48.

Noro, C.K.; López-Greco, L.S. and Buckup, L. 2008. Gonad morphology and type of sexuality in Parastacus defossus Faxon 1898, a burrowing, intersexed crayfish from southern Brazil (Decapoda: Parastacidae). Acta Zoologica, 89: 59-67.

Reid, J.W.; Noro, C.K.; Buckup, L. and Bisol, J. 2006. Copepod crustaceans from burrows of Parastacus defossus Faxon, 1898 in southern Brazil. Nauplius, 14: 23-30. 
Ribeiro, F.B.; Buckup, L.; Gomes, M. and Araujo, P.B. 2016. Two new species of South American freshwater crayfish genus Parastacus Huxley, 1819 (Crustacea: Decapoda: Parastacidae). Zootaxa, 4158: 301-324.

Santos, S.; Bond-Buckup, G.; Pérez-Losada, M.; BartholomeiSantos, M.L. and Buckup, L. 2009. Aegla manuinflata a new species of freshwater anomuran (Decapoda: Anomura: Aeglidae) from Brazil, determined by morphological and molecular characters. Zootaxa, 2088: 31-40.

Santos, S.; Bond-Buckup, G.; Pérez-Losada, M.; Jara, C.G.; Crandall, K.A. and Buckup, L. 2010. New records and description of a new species of Aeglidae (Crustacea, Anomura) from river basins in southern Brazil. Nauplius, 18:79-86.

Setz, E.Z.P. and Buckup, L. 1977. A duração da intermuda e o comportamento reprodutivo de Macrobrachium borellii e Palaemonetes argentinus no cultivo em laboratório (Crustacea,
Decapoda, Palaemonidae). Revista Brasileira de Biologia, 37: 899-906.

Silva-Castiglioni, D.; Oliveira, G.T. and Buckup, L. 2010. Metabolic responses of Parastacus defossus and Parastacus brasiliensis (Crustacea, Decapoda, Parastacidae) to hypoxia. Comparative Biochemistry and Physiology. A, Molecular \& Integrative Physiology, 156: 436-444.

Sokolowicz, C.C.; Bond-Buckup, G. and Buckup, L. 2006. Dynamics of gonadal development of Aegla platensis Schmitt (Decapoda, Anomura, Aeglidae). Revista brasileira de Zoologia, 23: 1153-1158.

Vinagre, A.S.; Ribarcki, F.P.; Amaral, A.P.N.; Chittó, A.L.F.; Noro, C.K.; Buckup, L. and Silva, R.S.M. 2004. Efeito de monoaminas sobre a contração muscular em crustáceos decápodes. Acta Scientiae (Ulbra), 6: 19-27. 